\title{
The use of intragastric nutrition to study saliva secretion and the relationship between rumen osmotic pressure and water transport
}

\author{
BY G. Y. ZHAO*, M. ĐURIĆ $\dagger$, N. A. MACLEOD, E. R. ØRSKOV, \\ F. D. DEB. HOVELL AND Y. L. FENG* \\ Rowett Research Institute, Bucksburn, Aberdeen AB2 9SB
}

(Received 8 September 1993 - Revised 4 April 1994 - Accepted 26 April 1994)

\begin{abstract}
Four sheep sustained by intragastric nutrition were used to study saliva secretion and the relationship between osmotic pressure in the rumen and net water transport across the rumen wall. Different concentrations of buffer were infused into the rumen to change the rumen osimotic pressure. Salivary secretion was estimated from entrance of $P$ into the rumen. Net water transport across the rumen wall was calculated as the difference between water inflow and water outflow from the rumen. $A$ negative linear relationship between the rumen osmotic pressure $(X, \mathrm{mOsm} / \mathrm{kg})$ and the water absorption across the rumen wall $(Y, \mathrm{ml} / \mathrm{h})$ was found: $Y=(394 \mathrm{SE} \mathrm{8.3})-\left(1.22 \mathrm{SE} \mathrm{0.03)} X, r^{2} 0.83,(P<0.001)\right.$, and a positive linear relationship was found between the rumen osmotic pressure $(X, \mathrm{mOsm} / \mathrm{kg})$ and the outflow rate of rumen fluid $(Y, \mathrm{ml} / \mathrm{h}): Y=(34.0 \mathrm{SE} 8.0)+(0.97 \mathrm{sE} \mathrm{0.03}) X, r^{2} 0.56,(P<0.001)$. The implication is that rumen osmotic pressure can be a key factor in the control of the net water transport across the rumen wall, the outflow of rumen fluid to omasum and the rumen liquid dilution rate. $A$ method is suggested by which salivary secretion in sheep may be calculated from the water balance in the rumen.
\end{abstract}

Osmotic pressure: Rumen: Saliva: Water absorption

Salivary secretion along with water intake accounts for the major part of the liquid turnover in the rumen since the rumen epithelium has no secretion of its own. Consequently, saliva plays an important role in the control of rumen fermentation and digestion. However, there is no satisfactory method for the measurement of total salivary secretion under normal conditions. The commonly used method requires catheterization of parotid glands and the assumption that this secretion is $50 \%$ of total. Catheters are not entirely satisfactory since they are not only difficult to maintain for a long time, but they also affect the rate of salivary secretion. MacKintosh (1984) used salivary P as a marker to estimate salivary secretion in normally fed sheep on the assumption that the rumen epithelium is impermeable to $P$. Estimations are however not very satisfactory because of the difficulty of separating the salivary $\mathbf{P}$ from feed $\mathbf{P}$. The liquids entering the rumen include saliva, water intake (drinking water and water in feeds) and water influx across the rumen wall; the liquids leaving the rumen include outflow to the lower digestive tract and absorption across the rumen wall. The water intakes and outflows of liquids are readily measured but the measurements of saliva and of water absorption (net water transport across the rumen wall) are more complicated. However, if the relationship between water absorption and rumen osmotic pressure (OP) can be established, it may be possible to calculate salivary secretion according to the water balance in the rumen. Warner \& Stacy (1972) studied the relationship between rumen $O P$ and net water absorption across the rumen wall within the OP range of $180-550 \mathrm{mOsm} / \mathrm{kg}$ in normally fed sheep. The saliva was diverted through an

* Present address: Department of Animal Science, Beijing Agricultural University, Beijing 100094, China.

$\dagger$ For reprints. 
oesophageal cannula and artificial saliva was infused into the rumen instead. They found a significant linear relationship between rumen OP and water absorption across the rumen wall. This was confirmed by Hovell \& Lopez (1993) within the OP range of $260-490 \mathrm{mOsm} / \mathrm{kg}$ in sheep nourished by intragastric infusions. However, these authors did not measure salivary secretion. The use of intragastric nutrition provides a tool with which salivary flow may be estimated. Since there is no feed $P$ entering the rumen, the $P$ can be assumed to be of salivary origin and since there is no absorption of $P$ from the rumen, it is possible to determine saliva secretion from concentration of $P$ in saliva and in rumen fluid. Determination of saliva secretion also requires an estimate of rumen liquid outflow. The study presented here is an attempt to determine salivary secretion using inorganic salivary $\mathbf{P}$ as a marker and, from this, to examine the relationship between rumen $O P$ and absorption of liquid across the rumen wall within the rumen OP range of 150-350 mOsm $/ \mathrm{kg}$. Net water absorption was calculated from rumen water balance with intake, outflow and saliva secretion all estimated separately and the precise relationship between water absorption and the rumen $O P$ established so that it can subsequently be used to make some estimate of saliva secretion in normally fed sheep.

\section{MATERIALS AND METHODS}

Four male adult Suffolk sheep weighing 26.9 (SE 0.25) $\mathrm{kg}$ were each fitted with a rumen cannula and an abomasal catheter. The rumen cannula and abomasal catheter were similar to those used by Ørskov et al. (1979). The animals were randomly divided into two pairs. The volatile fatty acids (VFA), buffer, casein, mineral, vitamin and trace mineral solutions for infusion were prepared according to MacLeod et al. (1982) (Table 1). Different concentrations of buffer were infused into the rumen to change the rumen osmotic pressure. The energy and protein levels infused daily were $540 \mathrm{~kJ} / \mathrm{kg}^{0.75}$ and $455 \mathrm{mg} \mathrm{N} / \mathrm{kg}^{0.75}$ respectively where maintenance energy was assumed to be $450 \mathrm{~kJ} / \mathrm{kg}^{0.75}$ and maintenance $\mathrm{N}$ to be $350 \mathrm{mg} \mathrm{N} / \mathrm{kg}^{\mathbf{0 7 7}}$. The energy was derived from four sources: VFA mixture (molar proportions of acetic-propionic-butyric acids $(65: 25: 10)$, maize oil, glucose and casein. In order to keep the rumen OP within a low range the VFA mixture was reduced and maize oil and glucose were increased as parts of the energy source. The protein source was casein and daily total volume of infusates was calculated to be $0.901 / \mathrm{kg} \mathrm{W}^{0.75}$ of which $0.691 / \mathrm{kg} \mathrm{W}^{0.75}$ was directed to the rumen.

The infusion level was increased gradually in the first $7 \mathrm{~d}$ of the experiment so that the animals could adapt to the infusions. When the targeted levels of energy, protein and infusion volumes had been reached the animals were maintained at these infusion levels for $7 \mathrm{~d}$. The $\mathrm{pH}$ and $\mathrm{OP}$ of the rumen fluid were measured four times daily and the $\mathrm{pH}$ kept above 5.6 by infusion of buffer solution into the rumen to ensure that the sheep were in healthy condition. As rumen $\mathrm{pH}$ in one sheep dropped to 5.5 when a low concentration of buffer $(250 \mathrm{~g} / \mathrm{d})$ was infused, the treatment was discontinued and so there were only twenty-three observations.

Rumen water volume and outflow were determined by use of marker solutions. CrEDTA solution was prepared according to the method of Binnerts et al. (1968) and CoEDTA according to the method of Udén et al. (1980). Two days before experimental treatments were started, $40 \mathrm{ml}$ CrEDTA solution (concentration about $2.5 \mathrm{mg} / \mathrm{ml}$ ) were divided between the buffer and VFA solutions to give the same $\mathrm{Cr}$ concentration in each infusate and the solutions were infused continuously into the rumen from 09.00 hours. Next day, at $10.00,14.00,18.00$ and 22.00 hours, rumen fluid samples were taken from each sheep and the $\mathrm{Cr}$ concentration was determined to assure that the plateau had been reached. The concentration of buffer for one group of sheep was then gradually increased and that for 
Table 1. Preparation of infusate

\begin{tabular}{|c|c|c|}
\hline Stock solution & $\mathrm{g} / \mathrm{kg}$ & Final solution (daily) \\
\hline \multicolumn{3}{|l|}{$\begin{array}{l}\text { Infusion into the rumen } \\
\text { VFA solution }\end{array}$} \\
\hline Acetic & 388.2 & Stock solution $288 \mathrm{~g}$ \\
\hline Propionic & 183.9 & Water up to $2600 \mathrm{ml}$ \\
\hline Butyric & 87.8 & \\
\hline $\mathrm{CaCO}_{3}$ & 18.0 & \\
\hline Water & $322 \cdot 1$ & \\
\hline \multicolumn{3}{|l|}{ Buffer solution } \\
\hline $\mathrm{NaHCO}_{3}$ & $73 \cdot 0$ & Stock solution: 250,500 \\
\hline $\mathrm{KHCO}_{3}{ }^{3}$ & $38 \cdot 0$ & $1000,1500,2000$ or $2500 \mathrm{~g}$ \\
\hline $\mathrm{NaCl}$ & $7 \cdot 0$ & Water up to $5600 \mathrm{ml}$ \\
\hline Water & $882 \cdot 0$ & \\
\hline \multicolumn{3}{|c|}{$\begin{array}{l}\text { Infusion into the abomasum } \\
\text { Casein solution }\end{array}$} \\
\hline Casein (89\% DM) & & Stock solution $404 \mathrm{~g}$ \\
\hline $\mathrm{Na}_{2} \mathrm{CO}_{3}$ & $5 \cdot 3$ & Glucose $91 \mathrm{~g}$ \\
\hline Vitamin solution* & 25.7 & Maize oil $37 \mathrm{~g}$ \\
\hline Water & 869.0 & Water up to $2400 \mathrm{ml}$ \\
\hline
\end{tabular}

VFA, volatile fatty acid; DM, dry matter.

* Prepared according to MacLeod et al. (1982).

the other group decreased. Other infusates remained constant (Table 1). Each treatment lasted $2 \mathrm{~d}$. On the first day of treatment, $\mathbf{4 0} \mathrm{ml} \mathrm{CrEDTA}$ solution were infused continuously into the rumen from 09.00 hours, as in the pre-treatment period, to allow measurement of the outflow rate of rumen fluid. On the second day of treatment, at 10.00, 14.00, 18.00 and 22.00 hours, $50 \mathrm{ml}$ rumen fluid were taken from each sheep. Then $10 \mathrm{ml}$ CoEDTA solution (concentration $172 \mathrm{~g} \mathrm{CoEDTA} / 1$ ) were dosed into the rumen through the rumen cannula by syringe to measure the rumen fluid volume. The marker was thoroughly mixed by the syringe. Immediately, about $50 \mathrm{ml}$ rumen fluid was taken. All samples were centrifuged at $2700 \mathrm{~g}$ for $20 \mathrm{~min}$ and the $\mathrm{OP}$ and $\mathrm{pH}$ were measured immediately. The samples were stored at $-20^{\circ}$ until analysed for $\mathrm{Cr}, \mathrm{Co}$ and inorganic $\mathrm{P}$. Saliva samples were taken at the time of CoEDTA dosing. They were obtained using a sponge which was about $100 \times 100 \times 20 \mathrm{~mm}$ in size to assure that total mixed saliva was soaked up. The sponge was retained in the mouths of sheep by a loop of string running behind the head for approximately $10 \mathrm{~min}$. The saliva from the sponge was then squeezed into a vial. The saliva samples were frozen for the analysis of inorganic $\mathrm{P}$.

\section{Chemical analysis and measurements}

$\mathrm{Cr}$ and Co were determined by atomic absorption spectrophotometry and inorganic $\mathrm{P}$ by a colorimetric method (Young, 1966). Rumen OP was measured with a freezing point depression osmometer (Precision System Inc., Natick, MA, USA) and rumen pH with a standard $\mathrm{pH}$ meter.

\section{Calculations}

With the assumption that markers were mixed with the rumen fluid instantaneously and completely and that the rumen was in steady state (i.e. that the rumen fluid volume was constant and the inflow and outflow of fluid were equal and constant), the outflow rate of rumen fluid $(F, \mathrm{ml} / \mathrm{h})$ to the omasum was calculated from the infusion rate into the rumen $(R, \mathrm{ml} / \mathrm{h})$, the concentration of $\mathrm{Cr}$ in the infusate $(M, \mathrm{mg} / \mathrm{ml})$ and the concentration of $\mathrm{Cr}$ 
in rumen fluid $(C, \mathrm{mg} / \mathrm{ml}): F=R \times M / C$. The rumen fluid volume $(V, \mathrm{ml})$ was calculated from the amount of Co dosed $(N, \mathrm{mg})$ and the concentration of Co in rumen fluid extrapolated to time of dosing and corrected for concentration of Co pre-dosing ( $A$, $\mathrm{mg} / \mathrm{ml}): V=N / A$. The rumen fluid dilution rate $(K$, fraction $/ \mathrm{h})$ was calculated as: $K=$ $F / V$. The rumen volume and the outflow rate of rumen fluid were the averages of four measurements during each day of treatment. The rate of salivary secretion $\left(R_{\mathrm{s}}, \mathrm{ml} / \mathrm{h}\right)$ was calculated along with the determination of inorganic $P$ concentration in rumen fluid and saliva:

$$
R_{s}=C_{r} \times R_{r} / C_{s},
$$

where $C_{r}$ is the concentration of inorganic $\mathrm{P}$ in rumen fluid $(\mathrm{mg} / \mathrm{ml}), R_{r}$ is the outflow rate of rumen fluid $(\mathrm{ml} / \mathrm{h})$ and $C_{s}$ is the concentration of inorganic $P$ in saliva $(\mathrm{mg} / \mathrm{ml})$. Net water absorption across the rumen wall was calculated as the difference between water inflow (infusion into the rumen + saliva secretion) and water outflow to the omasum.

\section{RESULTS AND DISCUSSION}

Results are shown in Table 2. The rumen OP was increased within the range of $149-338 \mathrm{mOsm} / \mathrm{kg}$ by increasing the concentration of buffer infused. Water absorption across the rumen wall decreased and rumen fluid dilution rate increased as the rumen OP increased. The rumen $\mathrm{pH}$ also increased as the concentration of buffer increased. Four measurements of the concentrations of inorganic $P$ in saliva and rumen fluid during each day of treatment were constant, but there were variations between different treatments. The concentration of inorganic $\mathbf{P}$ in rumen fluid decreased with the increase of concentration of buffer. The variation in salivary $\mathbf{P}$ concentration was higher than that in rumen fluid. Since in the sheep sustained by intragastric infusion there was no chewing or rumination, the normal stimuli to salivation, the salivary flow was very low and the concentration of salivary $\mathbf{P}$ high. On the other hand, the rumen fluid volume was not affected to any extent by experimental treatments and was similar to that in normally fed sheep. The volume of fluid in the rumen was consequently much larger than the volume of saliva secreted and so when the saliva reached the rumen, salivary $\mathbf{P}$ was diluted and variation in $\mathbf{P}$ concentration reduced.

The infusion rates of buffer and VFA solution were known, and salivary secretion and the outflow rate of rumen fluid were calculated by the methods mentioned above. On the assumption that the rumen was in a steady state, water absorption across the rumen wall could then be calculated according to the water balance of the rumen (Fig. 1).

A functional relationship between the rumen $\mathrm{OP}(X, \mathrm{mOsm} / \mathrm{kg})$ and water absorption across the rumen wall $(Y, \mathrm{ml} / \mathrm{h}$ ) was fitted using the MLP program (Ross, 1987) and a close correlation was found

$$
Y=\left(394 \text { SE 8.3) }-\left(1.22 \text { SE 0.03) } X, r^{2} 0.83, P<0.001\right. \text { (Fig. 2) : }\right.
$$

This relationship indicates that rumen $\mathrm{OP}$ is closely related to water absorption across the rumen wall. This relationship is similar to that given by Warner \& Stacy (1972) in normally fed sheep, $Y=0.404-0.001206 X$ (SE 0.053) $(n=47 ; r-0.90)$, where $Y$ was water absorption $(1 / \mathrm{h})$ and $X$ was rumen OP (mOsm $/ \mathrm{kg})$. Hovell \& Lopez (1993) estimated net water flux across the rumen wall as the difference between liquid infused and rumen outflow with the assumption that saliva secretion in sheep nourished by intragastric nutrition is negligible. They also found a significant correlation: $W=0.440-0.00128 \mathrm{OP}(n=16$; $\left.r^{2} 0.57\right)$, where $W$ was water absorption $(1 / \mathrm{h})$ and OP was rumen osmotic pressure $(\mathrm{mOsm} / \mathrm{kg})$. Our relationship shows that when the rumen OP increased, water absorption across the rumen wall decreased. When the rumen $\mathrm{OP}$ is zero, the water absorption across 
Table 2. Rumen osmotic pressure and water balance in sheep on intragastric nutrition* (Mean values with their standard errors for four sheep)

\begin{tabular}{|c|c|c|c|c|c|c|c|c|c|c|c|c|}
\hline & \multicolumn{12}{|c|}{ Treatments (concentrated buffer, $\mathrm{g} / \mathrm{d}$ ) } \\
\hline & \multicolumn{2}{|c|}{$250 \dagger$} & \multicolumn{2}{|c|}{500} & \multicolumn{2}{|c|}{1000} & \multicolumn{2}{|c|}{1500} & \multicolumn{2}{|c|}{2000} & \multicolumn{2}{|c|}{2500} \\
\hline & Mean & SE & Mean & $\mathrm{SE}$ & Mean & $\mathrm{SE}$ & Mean & SE & Mean & SE & Mean & SE \\
\hline $\begin{array}{l}\text { Water infusion } \\
\text { rate }(\mathrm{ml} / \mathrm{h})\end{array}$ & 285 & 3.2 & 299 & $8 \cdot 5$ & 288 & $5 \cdot 1$ & 276 & 9.3 & 305 & $5 \cdot 5$ & 309 & 6.1 \\
\hline $\begin{array}{l}\text { Osmotic pressure } \\
(\mathrm{mOsm} / \mathbf{k g})\end{array}$ & 149 & 6.7 & 191 & $11 \cdot 8$ & 216 & $7 \cdot 2$ & 251 & $4 \cdot 2$ & 308 & $5 \cdot 9$ & 338 & 6.5 \\
\hline $\begin{array}{l}\text { Net water } \\
\text { absorption }(\mathrm{ml} / \mathrm{h})\end{array}$ & 236 & $21 \cdot 8$ & 142 & $20 \cdot 0$ & 119 & $15 \cdot 1$ & 93 & $5 \cdot 3$ & 25 & $15 \cdot 3$ & -22 & $19 \cdot 6$ \\
\hline $\begin{array}{l}\text { Rumen water } \\
\text { volume (ml) }\end{array}$ & 3440 & 280 & 3880 & 410 & 2945 & 480 & 3335 & 580 & 2490 & 185 & 2228 & 430 \\
\hline $\begin{array}{l}\text { Rumen water } \\
\text { outflow (ml } / \mathrm{h})\end{array}$ & 216 & $45 \cdot 2$ & 235 & $42 \cdot 3$ & 224 & $29 \cdot 4$ & 241 & 5.8 & 320 & 10.6 & 385 & $21 \cdot 1$ \\
\hline $\begin{array}{l}\text { Rumen dilution } \\
\text { rate }(\% / \mathrm{h})\end{array}$ & 6.2 & 1.26 & $6 \cdot 2$ & 1.03 & 8.0 & 1.21 & 8.0 & 1.09 & $13 \cdot 2$ & 1.25 & $13 \cdot 1$ & 2.54 \\
\hline $\begin{array}{l}\text { Rumen pH } \\
\text { Salivary } \\
\text { phosphorus (mg/l) }\end{array}$ & $\begin{array}{l}6 \cdot 1 \\
389\end{array}$ & $\begin{array}{l}0 \cdot 23 \\
77 \cdot 1\end{array}$ & $\begin{array}{l}5 \cdot 6 \\
725\end{array}$ & $\begin{array}{r}0.41 \\
154 \cdot 4\end{array}$ & $721^{7 \cdot 3}$ & $\begin{array}{c}0.12 \\
105 \cdot 3\end{array}$ & $\begin{array}{l}7.9 \\
469\end{array}$ & $\begin{array}{l}0.05 \\
72 \cdot 4\end{array}$ & $\begin{array}{c}8 \cdot 0 \\
648\end{array}$ & $\begin{array}{l}0.03 \\
129.8\end{array}$ & $\begin{array}{c}8 \cdot 1 \\
549\end{array}$ & $\begin{array}{l}0.12 \\
117.0\end{array}$ \\
\hline $\begin{array}{l}\text { Rumen } \\
\text { phosphorus (mg/l) }\end{array}$ & 227 & 16.7 & 170 & 10.0 & 121 & $21 \cdot 9$ & 101 & $17 \cdot 7$ & 71 & $17 \cdot 7$ & 65 & $10-0$ \\
\hline $\begin{array}{l}\text { Salivary } \\
\text { secretion }(\mathrm{ml} / \mathrm{h})\end{array}$ & 167 & 63.2 & 78 & 27.7 & 55 & 24.8 & 57 & 13.8 & 40 & $10 \cdot 8$ & 54 & $12 \cdot 3$ \\
\hline
\end{tabular}

* For details of procedures, see pp. 156-158.

+ Three observations only.

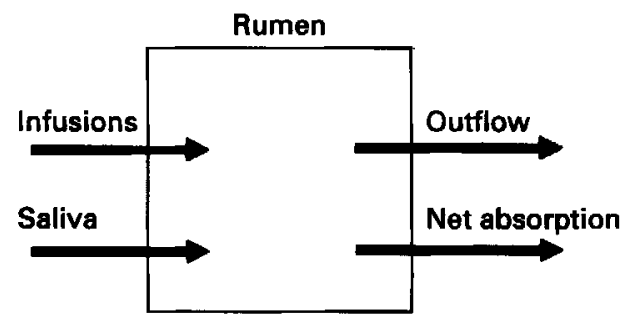

Fig. 1. Water balance in the rumen of sheep on intragastric infusion.

the rumen wall estimated by extrapolation is about 9.5 (SE 0.20$) 1 / \mathrm{d}$, and when the OP of rumen fluid is about $323 \mathrm{mOsm} / \mathrm{kg}$, the net water transport across the rumen wall is about zero (SE 0.43) $1 / \mathrm{d}$.

The functional relationship between the rumen $O P(X, \mathrm{mOsm} / \mathrm{kg})$ and the outflow rate of rumen fluid to the omasum $(Y, \mathrm{ml} / \mathrm{h})$ was also significant: $Y=(34.0 \mathrm{sE} 8.0)+(0.97 \mathrm{SE}$ 0.03 ) $X, r^{2} 0.56, P<0.001$ (Fig. 3). This relationship was in agreement with that between the rumen $O P$ and the water absorption across the rumen wall and explained that when the rumen OP increased, the rate of water absorption across the rumen wall decreased and the water which was not absorbed across the rumen wall flowed out of the rumen to the omasum, so increasing the outflow rate of rumen fluid. It was also in agreement with the statement of Harrison et al. (1975) that the outflow rate of rumen fluid can be changed by altering the rumen $O P$. 


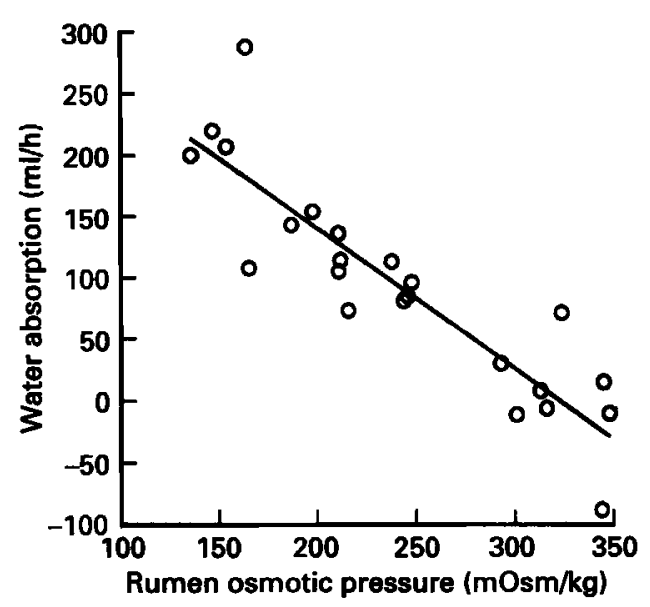

Fig. 2. Relationship between rumen osmotic pressure and water absorption across the rumen wall in sheep.

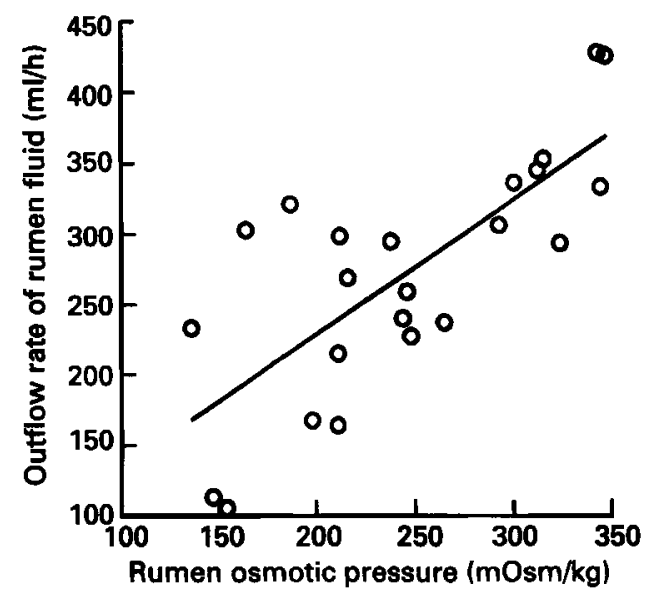

Fig. 3. Relationship between rumen osmotic pressure and outflow rate of rumen fluid in sheep.

Salivary $\mathbf{P}$ has previously been used as a marker for estimation of salivary secretion in sheep by MacKintosh (1984). The same procedures were used in the present experiment, but the animals were wholly sustained by intragastric nutrition, and so there was only liquid phase in the rumen. The liquid marker could easily be mixed with the rumen fluid in this condition, and the $\mathbf{P}$ in the rumen fluid came only from the saliva so that there was no need to distinguish salivary $\mathbf{P}$ from feed $\mathbf{P}$. Consequently, our estimates of salivary flow are likely to be more precise than those given by MacKintosh (1984).

Rumen variables in our trial were constant because the solutions were infused continuously and the rumen contained liquid phase only. However, as sheep normally do not eat continuously and as the rumen normally contains a non-homogeneous mass of feed and digesta these variables may have a diurnal pattern. The presence of feed may also affect the rumen motility and the permeability of the rumen wall which in turn could have an influence on the relationship presented here between rumen OP and water absorption across the rumen wall. 


\section{CONCLUSIONS}

As expected, it was shown that rumen OP controls water transport across the rumen wall. The results presented in the present paper suggest that the rumen $O P$ can be used to calculate net water flux across the rumen wall. If the drinking water and food water, the outflow rate of rumen fluid and the rumen liquid volume are known, it is then possible to calculate salivary secretion from the water balance in the rumen. More research is needed to estimate possible effects of the presence of feed in the rumen on the relationship between rumen $\mathrm{OP}$ and water absorption across the rumen wall before the outlined method can be applied to determine salivary flow in normally fed animals.

The authors thank Dr J. Price and Mr R. Humphries for help in determination of Cr and Co, Miss M. G. Annand and Mrs M. Tucker for determination of P and Dr X. B. Chen for helpful discussions. We also thank the Scottish Office Agricultural and Fisheries Department for financial support.

\section{REFERENCES}

Binnerts, W. T., van't Klooster, A. T. \& Frens, A. M. (1968). Soluble chromium indicator measured by atomic absorption in digestion experiments. Veterinary Record 20, 470.

Harrison, D. G., Beever, D. E., Thomson, D. J. \& Osbourn, D. F. (1975). Manipulation of rumen fermentation in sheep by increasing the rate of flow of water from the rumen. Journal of Agricultural Science, Cambridge 85, 93-101.

Hovell, F. D. DeB. \& Lopez, S. (1993). Rumen osmotic pressure, water flux and volatile fatty acid (VFA) absorption in sheep. Proceedings of the Nutrition Society 52, 181A.

MacKintosh, J. B. (1984). Salivation, rumination and the passage of digesta through the forestomach of the sheep. In Ruminant Physiology. Concepts and Consequences, pp. 67-77. [S. K. Baker, J. M. Grawthorne and J. B. MacKintosh, editors]. Perth: University of Western Australia.

MacLeod, N. A., Corrigall, W., Stirton, R. A. \& Ørskov, E. R. (1982). Intragastric infusion of nutrients in cattle. British Journal of Nutrition 47, 547-552.

Ørskov, E. R., Grubb, D. A., Wenham, G. \& Corrigall, W. (1979). The sustenance of growing and fattening ruminants by intragastric infusion of volatile fatty acid and protein. British Journal of Nutrition 41, 553-558.

Ross, G. J. S. (1987). MLP 3.08. Rothamsted Experimental Station. Oxford: Numerical Algorithms Group Ltd.

Udén, P., Colucci, P. E. \& Van Soest, P. J. (1980). Investigation of chromium, cerium and cobalt as markers in digesta rate of passage studies. Journal of the Science of Food and Agriculture 31, 625-632.

Warner, A. C. I. \& Stacy, B. D. (1972). Water, sodium and potassium movement across the rumen wall of sheep. Quarterly Journal of Experimental Physiology 57, 103-119.

Young, D. S. (1966). Improved method for the automatic determination of serum inorganic phosphate. Journal of Clinical Pathology 19, 397-399. 